\title{
Bone Injury
}

National Cancer Institute

\section{Source}

National Cancer Institute. Bone Injury. NCI Thesaurus. Code C35487.

Trauma to bone. 